\title{
Inventaire des mégalithes
}

Capdenac-Gare, Villefranche-de-Rouergue, Villeneuve (Aveyron)

\section{(2) OpenEdition \\ Journals}

Édition électronique

URL : http://journals.openedition.org/adlfi/10530

ISSN : 2114-0502

\section{Éditeur}

Ministère de la culture

\section{Référence électronique}

«Inventaire des mégalithes », ADLFI. Archéologie de la France - Informations [En ligne], Midi-Pyrénées, mis en ligne le 01 mars 1997, consulté le 25 avril 2019. URL : http://journals.openedition.org/ adlfi/10530

Ce document a été généré automatiquement le 25 avril 2019

(c) Ministère de la Culture et de la Communication, CNRS 


\title{
Inventaire des mégalithes
}

\author{
Capdenac-Gare, Villefranche-de-Rouergue, Villeneuve (Aveyron)
}

\author{
Date de l'opération : 1991 (PI) \\ Inventeur(s) : Fayet de la Tour Alain du
}

1 À la suite d'un projet d'aménagement de circuit touristique autour des dolmens de la commune de Foissac, Alain du Fayet de la Tour, a repris le recensement des mégalithes de cette zone occidentale de l'Aveyron, géographiquement rattachée au Quercy.

2 Un précédent inventaire avait été réalisé une douzaine d'années auparavant (Clottes, Maurand, 1983) et il était intéressant d'effectuer un contrôle systématique de l'état de conservation de la centaine de monuments décrits. Ceux-ci sont en effet presque toujours isolés sur le causse où l'activité agricole est en voie d'abandon. Ce travail offre l'opportunité de préciser ou de compléter certaines données (coordonnées, cadastre, propriétaires, plan d'accès, etc.). Une méthodologie de référence qui a été mise au point, est maintenant appliquée à d'autres régions et à d'autres sites archéologiques.

Une carrière de dalles mégalithiques, un nouveau dolmen, un monument dont le statut devra être précisé et une série de dalles gravées ont été découverts lors de cette opération de contrôle.

\section{INDEX}

Index chronologique : Néolithique

operation Prospection inventaire (PI) 